\title{
Immunomodulatory effects of Rhodomyrtus tomentosa leaf extract and its derivative compound, rhodomyrtone on head kidney macrophages of rainbow trout
}

\section{(Oncorhynchus mykiss)}

Pinanong Na-Phatthalung $\cdot$ Mariana Teles $\cdot$ Supayang Piyawan Voravuthikunchai $\cdot$ LluísTort $\cdot$ Camino Fierro-Castro

P. Na-Phatthalung $\cdot$ S.P. Voravuthikunchai

Department of Microbiology and Excellence Research Laboratory on Natural Products, Faculty of Science and Natural Product Research Center of Excellence, Prince of Songkla University, Hat Yai, Songkhla 90112, Thailand

M. Teles $\cdot$ L. Tort $\cdot$ C. Fierro-Castro $(\bowtie)$

Department of Cell Biology, Physiology and Immunology, Universitat Autònoma de Barcelona, Barcelona 08193, Spain

e-mail: mariacamino.fierro@uab.ca

Post-print of: Na-Phatthalung, P. et al. "Immunomodulatory effects of Rhodomyrtus tomentosa leaf extract and its derivative compound, rhodomyrtone, on head kidney macrophages of rainbow trout (Oncorhynchus mykiss)" in Fish physiology and biochemistry (Springer), vol. 44, issue 2 (2018) p. 543-555. The final version is available at DOI 10.1007/s 10695-017-0452-2 under the terms of the cop. All rights reserved license 


\begin{abstract}
Rhodomyrtus tomentosa is a medicinal plant that shows biological effects including immunomodulatory activity on human and other mammals, but not in fish. In this study, we evaluated the in vitro immunomodulatory effects of Rhodomyrtus tomentosa leaf extract and its active compound, rhodomyrtone on the immune responses, using rainbow trout (Oncorhynchus mykiss) head kidney (HK) macrophages as a model. The tested immune functions included the expression of genes involved in innate immune and inflammatory responses and the production of reactive oxygen species (ROS). Gene expression was evaluated after exposure to $10 \mu \mathrm{g} \mathrm{mL}^{-1}$ of $R$. tomentosa and $1 \mu \mathrm{g} \mathrm{mL}^{-1}$ of rhodomyrtone for 4 and 24 h. $R$. tomentos $a$ and rhodomyrtone induced changes in the expression of pro-inflammatory cytokines (ill $\beta, i l 8$, and $\operatorname{tnf} \alpha)$, anti-inflammatory cytokines (illo and $\operatorname{tg} f \beta$ ), inducible enzymes (inos, cox2, and arginase), and an antioxidant enzyme (gpxl). Co-exposure of $R$. tomentosa with LPS resulted in a prominent reduction in the expression of genes related to an inflammatory process $(i l 1 \beta, i l 8$, tnf $\alpha$, inos, saa, hepcidin, and gpxl), suggesting anti-inflammatory effects. Similarly, coexposure of rhodomyrtone with LPS led to a down-regulation of inflammation-related genes (ill $\beta$, inos, saa, and hepcidin). In addition, exposure to both natural plant products caused a reduction in cellular ROS levels by HK macrophages. The present results indicate that $R$. tomentosa and rhodomyrtone exerted immunostimulatory and anti-inflammatory effects on fish macrophages, thus opening up the possibility of using these natural products to further develop immunostimulants for health management in aquaculture.
\end{abstract}

Keywords Immunomodulatory effects $\cdot$ Macrophages $\cdot$ Rhodomyrtus tomentosa $\cdot$ rhodomyrtone $\cdot$ Rainbow trout 


\section{Introduction}

The use of medicinal plants as an alternative way for disease control and health improvement in aquatic organisms has gain interest, due to increasing concerns on the detrimental effects of antibiotics and chemicals in aquacultured species and the environment. Natural plant products show multiple biological activities, such as antibacterial activities, anti-stress and growth-promoting effects, some of which providing benefits for fish health management (Van Hai 2015). In addition, they may be readily available, inexpensive, and have no hazardous effects because of low side effects on aquatic animals and environment (Van Hai 2015). Immunomodulatory activity is one of the prevalent properties of medicinal plants that are being widely examined in competition with other immunostimulators like lipopolysaccharides (LPS), $\beta$-glucan, chitosan (Sakai 1999), and flagellin (Wangkahart et al. 2016). Previous studies conducted in both in vitro and in vivo conditions reported that medicinal plants have a positive impact on fish immune responses, which renders higher degree of disease resistance and stress tolerance (Chakraborty and Hancz 2011; Harikrishnan et al. 2011). Experiments on animal models have clearly defined the advantages of plant products as an alternative to the chemical control and treatment of diseases. Nevertheless, variations depending on physical characteristics of animals (e.g. species, size, and sex), environment conditions (e.g. temperature, salinity, and water quality), and occurrence of stressors (e.g. container and restriction effects, catching and capture) need to be assessed in these models.

The use of cell lines and primary cell cultures derived from fish organs has been extensively used as in vitro models for determining the toxicity of aquatic pollutants (Fent 2001; Wang et al. 2011), as well as for the study of the immunomodulatory effects of various chemical and biological compounds including natural products (Yin et al. 2011; Picchietti et al. 2013; Villasante et al. 2016). For instance, a Sparus aurata fibroblast cell line (SAF-1) has been used to determine the immunostimulatory effects of Aloe arborescens at molecular level, evaluating the expression of immune-related genes (Picchietti et al. 2013). Primary myogenic cell preparations of rainbow trout (Oncorhynchus mykiss) were used to investigate the effects of anthocyanidins, a flavonoid-polyphenol compound of several vegetables as a promoter of myogenic differentiation and antioxidant defense (Villasante et al. 2016). Recently, two stromal cell lines derived from spleen (TSS), pronephros (TPS-2) and macrophages of rainbow trout have been used as in vitro models for immunostimulant studies in aquaculture (Fierro-Castro et al. 2012; Fierro-Castro et al. 2013). 
Rhodomyrtus tomentosa (Aiton) Hassk, is a Thai medicinal plant of the family Myrtaceae that can be found in tropical areas of Southeast Asia and some regions of Australia. Its immunopharmacological and chemopreventive properties have been studied and it has been reported to be an antioxidant (Lavanya et al. 2012), anti-inflammatory agent (Jeong et al. 2013) in mice models, while earlier in vitro studies reported a stimulatory activity of the plant extract on the differentiation of mouse osteoblastic cell lines (Tung et al. 2009). Rhodomyrtone, a pure compound of the acylphloroglucinol class isolated from $R$. tomentosa leaves, also promoted pro- and anti-inflammatory responses in human monocytes (Srisuwan et al. 2014). While this plant and its compounds have shown encouraging results in human and other mammals such as mouse (Lavanya et al. 2012; Jeong et al. 2013) and cow (Mordmuang et al. 2015), its potential on aquatic animals has not yet been investigated. In this context, the aim of the present study was to determine the immunomodulatory effects of not only the medicinal plant, $R$. tomentosa but also its active compound, rhodomyrtone on macrophages isolated from rainbow trout head kidney (HK) through changes in the expression of target genes related to innate immune responses. The target genes were selected based on the ability of $R$. tomentosa leaf extract or its phytochemical components (e.g. rhodomyrtone, quercetin, ursolic acid, tomentosin etc.) to modulate mRNAs relevant to immune defenses in mammals, as documented in previous studies (Manu and Kuttan 2008; Jeong et al. 2013; Srisuwan et al. 2014). In this study our objective focused on selected indicators of the innate immune function of fish, since the innate immune system of fish responds earlier and non-specifically to any challenge such as the exposure to these plant compounds. Moreover, since the adaptive response is more relevant at systemic level and longer exposure times, it would deserve another experimental approach. The selected genes included pro-inflammatory cytokines, such as interleukin $1 \beta($ ill $\beta)$, interleukin 8 (il8) and tumour necrosis factor- $\alpha(\operatorname{tnf} \alpha)$; immune-suppressing cytokines, namely interleukin $10(i l 10)$ and transforming growth factor beta $(\operatorname{tg} f \beta)$; inducible enzymes, such as inducible nitric oxide synthase (inos), cyclooxygenase-2 (cox2) and arginase; antimicrobial peptides and acute phase proteins, such as serum amyloid A $(s a a)$ and hepcidin, as well as antioxidant enzymes, namely NADPH oxidase (nadph) and glutathione peroxidase 1 (gpxl).

\section{Materials and methods}

R. tomentosa leaf extract and rhodomyrtone preparation

R. tomentosa leaves were collected from Khuan Lang, Songkhla Province in the southern part of Thailand. The voucher specimen was identified and deposited at Faculty of Traditional Thai Medicine, Prince of Songkla University, Thailand. An ethanol extract of $R$. tomentosa leaves was prepared according to the method 
of Limsuwan et al (2009). Rhodomyrtone was obtained from Natural Product Research Center of Excellence, Prince of Songkla University, Thailand. Rhodomyrtone was isolated from the leaves crude extracts of $R$. tomentosa using column chromatography (Hiranrat and Mahabusarakam 2008). A stock solution of $R$. tomentosa extract and rhodomyrtone was prepared by dissolving in $100 \%$ dimethyl sulphoxide (DMSO) and stored at $-20{ }^{\circ} \mathrm{C}$ until use. The stock plant solutions were diluted to appropriate final concentrations in cell culture medium. The final concentration of DMSO in the working solution was $0.4 \%$ which did not show any cytotoxic effect on fish macrophages.

Fish

O. mykiss weighing 150-200 g were obtained from a local fish farm, Trout Farm (Oliana, Spain). Fish were maintained in recirculating freshwater tanks, at $14{ }^{\circ} \mathrm{C}$, with a $12 \mathrm{~h}$ light per $12 \mathrm{~h}$ dark photoperiod. Fish were daily fed with a commercial diet (Trouw T6 Classics 3P, Trouw España, Spain). Dissolved oxygen ( $<9 \mathrm{mg}$ $\left.\mathrm{L}^{-1}\right), \mathrm{pH}(6.0-8.5)$, nitrite $\left(<0.05 \mathrm{mg} \mathrm{L}^{-1}\right)$, nitrate $\left(<1.0 \mathrm{mg} \mathrm{L}^{-1}\right)$, and ammonia $\left(<0.07 \mathrm{mg} \mathrm{L}^{-1}\right)$ were monitored along the whole experiment. Prior to experiments, fish were acclimatized to these conditions for 2 weeks, and observed during this period for any abnormal clinical sign. All experimental procedures involving fish were submitted and authorized by the Ethical Committee of the "Universitat Autònoma de Barcelona" that agrees with the International Guiding Principles for Biomedical Research Involving Animals (EU 2010/63).

Macrophage isolation and culture conditions

Fish were sacrificed by over-anesthetization with tricaine methane sulphonate (MS222, SigmaAldrich). Blood was removed from the caudal vein and HK were excised. HK macrophages were obtained according to the method described by Secombes (1990). Briefly, HK tissue was harvested aseptically and pushed through a nylon mesh $(100 \mu \mathrm{m})$ with $5 \mathrm{ml}$ of RPMI medium (Gibco) containing $2 \%$ fetal bovine serum (FBS), $50 \mathrm{mg} \mathrm{mL}^{-1}$ gentamicin, $2 \mathrm{mg} \mathrm{mL}^{-1}$ amphotericin $\mathrm{B}$, and 20 units $\mathrm{mL}^{-1}$ heparin. HK macrophages were isolated by centrifugation of the cell suspensions on a 34/51\% discontinuous Percoll gradient (400 g for $30 \mathrm{~min}$ at $4{ }^{\circ} \mathrm{C}$ ). The cells banding in the Percoll interface were collected, washed, and adjusted the cell suspension to 2 $\times 10^{7}$ viable cells $\mathrm{mL}^{-1}$ with RPMI medium containing $0.1 \% \mathrm{FCS}, 50 \mathrm{mg} \mathrm{mL}^{-1}$ gentamicin, and $2 \mathrm{mg} \mathrm{mL}^{-1}$ amphotericin B. The resultant cell suspension was seeded in 96-well plate for the cytotoxicity and respiratory burst tests and on 6-well plate for the gene expression study and incubated overnight at $18^{\circ} \mathrm{C}$ in air containing $5 \% \mathrm{CO}_{2}$. Purified plastic-adherent cells were cultured in fresh RPMI 1640 medium containing 5\% FBS, $50 \mathrm{mg}$ 
$\mathrm{mL}^{-1}$ gentamicin, and $2 \mathrm{mg} \mathrm{mL}^{-1}$ amphotericin B for $24 \mathrm{~h}$ before use. For the cytotoxicity and respiratory burst activity assays six fish were used ( $n=6)$ and for gene expression analysis three fish were used $(n=3)$.

\section{Cytotoxicity assay}

Evaluation of cytotoxic activity of $R$. tomentos $a$ and rhodomyrtone in fish cells was determined by MTT (3-[4,5-dimethylthiazol-2-yl]-2,5-diphenyltetrazolium bromide) reduction assay (Sigma-Aldrich). The MTT assay is based on the cellular uptake of MTT and its subsequent reduction in the mitochondria of living cells to MTT formazan. Dead cells do not cause this change. Fish cells $\left(2 \times 10^{7}\right.$ cells per well $)$ were seeded in 96-well tissue culture microtiter plates and allowed to adhere for $24 \mathrm{~h}$ under the cell culture conditions as described above. Subsequently, adherent cells were exposed to serial concentrations of R. tomentosa (2.5-400 $\left.\mu \mathrm{g} \mathrm{mL} \mathrm{m}^{-1}\right)$ or rhodomyrtone $\left(0.125-16 \mu \mathrm{g} \mathrm{mL} \mathrm{L}^{-1}\right)$, and its solvent $(0.4 \% \mathrm{DMSO})$ and cultured for another $24 \mathrm{~h}$. After incubation, the cells were gently washed with phosphate buffer solution (PBS) and new PBS was replaced into each well. Cell viability was assayed by adding $10 \mu \mathrm{L}$ of MTT ( $5 \mathrm{mg} \mathrm{mL}^{-1}$ in PBS) and incubated in the dark at $18{ }^{\circ} \mathrm{C}$ for $2 \mathrm{~h}$. Thereafter, supernatant containing MTT was discarded and $100 \mu \mathrm{L}$ of $100 \%$ DMSO were added to solubilize the intracellular formazan crystals. After thorough mixing, the absorbance was recorded at $570 \mathrm{~nm}$ using a microplate reader (PerkinElmer, Victor $^{3}$ ). Control wells had the same volume of medium without the plant substances. All the experiments were run in triplicate wells for each condition ( 3 fish per experiment), and independently repeated at least three times.

Percent viability was defined at the ratio of absorbance between the test samples and the positive control using the formula:

$\%$ viability $=\left(\mathrm{Abs}_{\text {sample }} / \mathrm{Abs}_{\text {control }}\right) \times 100$

Treatment of macrophages with $R$. tomentosa leaf extract and rhodomyrtone

Two experiments were done; in the first experiment HK macrophages $\left(2 \times 10^{7}\right.$ cells per well) were exposed to $R$. tomentosa $\left(10 \mu \mathrm{g} \mathrm{mL}^{-1}\right)$ or rhodomyrtone $\left(1 \mu \mathrm{g} \mathrm{mL} \mathrm{m}^{-1}\right)$ and sampled after 4 and 24 hours of exposure. These concentrations were chosen regarding the cytotoxicity results. To gain insight into the immunomodulatory effects of the natural plant products in relation with pathogens, a second experiment was carried out in HK macrophages exposed to R. tomentosa plus LPS or rhodomyrtone plus LPS for 4 and $24 \mathrm{~h}$. The concentration of LPS $\left(5 \mu \mathrm{g} \mathrm{mL} \mathrm{m}^{-1}\right)$ from Salmonella typhimurium (Sigma-Aldrich) was chosen based on previous studies showing that this concentration generates an inflammatory response in $\mathrm{HK}$ macrophages 
(Fierro-Castro et al. 2012; Fierro-Castro et al. 2013). R. tomentosa and rhodomyrtone concentrations were chosen based on the results of experiment 1. Unexposed cells were used as control groups. The assays were set up for use in gene transcription analysis as described below. The experiments were carried out in triplicate wells (3 fish per experiment), and independently repeated three times.

Gene transcription analysis

Total RNA from HK macrophages was extracted using TRI reagent (Sigma-Aldrich) following the manufacturer's instructions. Purity and concentration of total RNA were measured spectrophotometrically using a NanoDrop Reader (Thermo Fisher Scientific, USA). The verification of RNA integrity was assessed by running an aliquot of the sample pre-strained with bromophenol blue on a $1 \%$ agarose gel. One microgram of RNA was used as a template for cDNA systhesis, using iScript ${ }^{\mathrm{TM}}$ cDNA Synthesis Kit (Bio-Rad, USA). The resultant cDNA was stored at $-20^{\circ} \mathrm{C}$ until use. The GenBank identification and primer sequences are shown in Table 1.

PCR amplification was assayed with the SYBR green method using a iQ5 iCycler thermal cycler (BioRad). The reactions were set up in a 384-well plate according to manufacturer's procedures consisting of $1 \mu \mathrm{L}$ of cDNA template (1:10 dilution), $5 \mu \mathrm{L}$ of iTaq $^{\mathrm{TM}}$ Universal SYBR Green Supermix (Bio-Rad), $3.6 \mu$ of MilliQ water, and $0.2 \mu \mathrm{L}$ of forward and reverse primer $(0.1 \mathrm{mM})$. PCR cycling conditions were $95^{\circ} \mathrm{C}$ for $10 \mathrm{~s}$ followed by $60^{\circ} \mathrm{C}$ for $30 \mathrm{~s}$ with an initial denaturation step of $95^{\circ} \mathrm{C}$ for $3 \mathrm{~min}$. Fluorescence signal output was monitored at the end of each cycle for 40 cycles. All amplification reactions were run in triplicate for each sample. The relative expression ratios of target gene were calculated using the comparative threshold cycle $(\mathrm{Ct})$ method (Pfaffl 2001). PCR amplification efficiencies $(E)$ for each primer pair were assessed using a five-fold dilution series of pool cDNA. The efficiency was analyzed following the equation: $E=10^{[-1 / s]}$, where s is the slope generated from the serial dilutions of target nucleic acid, when Log dilution is plotted against $\mathrm{Ct}$ values. The expression of target genes was normalized against a reference gene $(e f 1 \alpha)$ following the equation: Ratio $=\left(E_{\text {target }}\right)^{\Delta \mathrm{Ct}}$ target ${ }^{(\text {control-sample })} /\left(E_{\text {ref }}\right)^{\Delta \mathrm{Ct}}$ ref $($ control-sample $)$

where $E_{\text {target }}$ is $E$ of the target gene transcript, $E_{\text {ref }}$ is $E$ of a reference gene transcript, $\Delta \mathrm{Ct}_{\text {target }}$ is crossing point (CP) deviation of control-sample of target gene transcript, and $\Delta \mathrm{Ct}_{\mathrm{ref}}$ is $\mathrm{CP}$ deviation of control-sample of reference gene transcript.

Reactive oxygen species (ROS) production 
Intracellular ROS production of the fish cells exposed to the plant products was investigated by nitroblue tetrazolium (NBT) reduction assay (Chung and Secombes 1988). In brief, cell monolayers were washed twice with HBSS and $100 \mu \mathrm{L}$ of $R$. tomentosa; $\left(10,50\right.$, and $\left.100 \mu \mathrm{g} \mathrm{mL}^{-1}\right)$ or rhodomyrtone $(1,2$, and 4 $\mu \mathrm{g} \mathrm{mL}^{-1}$ ) dissolved in RPMI medium plus $1 \mathrm{mg} \mathrm{mL}^{-1}$ of NBT was added and incubated in the dark at $18^{\circ} \mathrm{C}$ under $5 \% \mathrm{CO}_{2}$ for $1 \mathrm{~h}$. Thereafter, the supernatant was removed and the cellular pellet was fixed in methanol (Merck) for $15 \mathrm{~min}$ and then washed with $70 \%$ methanol. After fixation, the resultant formazan product was solubilized in $120 \mu \mathrm{L}$ of $2 \mathrm{M} \mathrm{KOH}$ and $140 \mu \mathrm{L}$ of DMSO with thorough mixing. The experiments were repeated two times and the results in each test were based on the mean of three fish per replicate. The absorbance for each sample solution was measured at $620 \mathrm{~nm}$ using a microplate reader. The index of exposed cells was calculated using the formula:

ROS production $(\%)=[($ sample-blank $) /($ control-blank $)]-1 \times 100$

Statistical analyses

Statistical analyses were performed using SPSS statistical software version 16 (SPSS Inc, IBM, Chicago, USA). Toxicity data was analyzed by one-way ANOVA using Tukey's test for multiple comparisons. For all the other parameters a two-way ANOVA was done considering, as main factors treatment and time. Statistical significance was assumed when $P<0.01$ or $P<0.05$.

\section{Results}

Cytotoxicity of $R$. tomentosa leaf extract and rhodomyrtone on HK macrophages

The results demonstrated that $R$. tomentosa and rhodomyrtone did not show any significant cytotoxic effect against HK macrophages at concentrations lower than 25 and $1 \mu \mathrm{g} \mathrm{mL}^{-1}$, respectively $(P<0.05)($ Fig. 1$)$. Meanwhile, $R$. tomentosa at $50 \mu \mathrm{g} \mathrm{mL}^{-1}$ and rhodomyrtone at $2 \mu \mathrm{g} \mathrm{mL}-1$ were slightly toxic (cell viability < $80 \%$ ) even though there was not statistically significant difference in cell viability between control and treated groups. The plant products exhibited cytotoxicity at higher concentrations in a concentration-dependent manner.

Effects of $R$. tomentosa leaf extract and rhodomyrtone on the expression of immune-related genes

In this study, the variation of immune-related genes was determined in HK macrophages after exposure to $10 \mu \mathrm{g} \mathrm{mL}^{-1}$ of $R$. tomentosa and $1 \mu \mathrm{g} \mathrm{mL}^{-1}$ of rhodomyrtone for 4 and $24 \mathrm{~h}$. Regarding pro-inflammatory cytokines (ill $\beta, i l 8$, and $\operatorname{tnf} \alpha$ ) gene expression, the HK macrophages exposed to $R$. tomentosa for $4 \mathrm{~h}$ presented 
significant upregulation of $i l 1 \beta$ (Fig.2) $(P<0.01)$. Meanwhile, exposure to rhodomyrtone for $4 \mathrm{~h}$ caused a significant upregulation of $i l 1 \beta, i l 8$, and $\operatorname{tnf} \alpha(P<0.01)$.

The expression of immune-suppressing cytokines, illO and $\operatorname{tg} f \beta$ in HK macrophages was not modified when exposed to R. tomentosa for 4 and 24 in comparison with the control group (Fig. 3). Of the parallel analysis, the mRNA level of these anti-inflammatory cytokines was not significantly changed after exposure to rhodomyrtone for $4 \mathrm{~h}$ as seen in $R$. tomentosa treated groups. However, after $24 \mathrm{~h}$, increased expression of both $i l 10$ and $\operatorname{tg} f \beta$ was detected in the fish cells $(P<0.05)$.

With respect to immune genes related to inducible enzymes, inos, cox2, and arginase, exposure of HK macrophages to $R$. tomentosa for 4 and 24 h had no significant effect on the alteration of these genes (Fig. 4). Treatment of fish cells with rhodomyrtone for $4 \mathrm{~h}$ did not modify the expression of inos, cox 2 , and arginase expression, whilst treatment with the compound for $24 \mathrm{~h}$ resulted in significant upregulation of all the genes $(P$ $<0.01)$.

In terms of genes influencing acute phase protein ( $s a a$ ), antimicrobial peptide (hepcidin), and antioxidant enzymes (nadph and gpxl), R. tomentosa failed to alter the expression of the target genes in HK macrophages after 4 and $24 \mathrm{~h}$ exposure (Fig. 5). On the other hand, the transcription of those genes was also unaffected by exposure to rhodomyrtone for 4 and $24 \mathrm{~h}$ with the exception of gpxl. The expression of gpxl was remarkably upregulated in response to rhodomyrtone after $24 \mathrm{~h}$ exposure $(P<0.01)$.

To gain insight into the immunomodulatory effects of the natural plant products in relation with pathogen contamination in aquatic ecosystems, the gene expression associated with innate immune response in HK macrophages exposed to a combination of $R$. tomentosa or rhodomyrtone and LPS was investigated. The results demonstrated that exposure to $R$. tomentosa plus LPS caused a significant decrease in the expression of $i l 1 \beta$, ils, inos, and hepcidin after $4 \mathrm{~h}(P<0.01)$, and then $24 \mathrm{~h}$ exposure led to a reduction in the expression of $i l 1 \beta, i l 8$, saa, and gpxl, compared with LPS alone $(P<0.01)$ (Fig. 6). The combined treatment with rhodomyrtone and LPS led to a significant reduction in the expression of ill $\beta$, inos, and hepcidin after $4 \mathrm{~h}$ exposure and the expression of saa, hepcidin, and gpxl after 24 h exposure $(P<0.01)$, but resulted in a synergistic upregulation of $\operatorname{tn} f \alpha$ after 4 and $24 \mathrm{~h}$ exposure in comparison with LPS alone $(P>0.05)$.

Effects of $R$. tomentosa leaf extract and rhodomrytone on ROS production

Concerning intracellular ROS production (superoxide anion), after exposure to $R$. tomentosa (10, 50, $\left.100 \mu \mathrm{g} \mathrm{mL}^{-1}\right)$ and rhodomyrtone $\left(1,2\right.$, and $\left.4 \mu \mathrm{g} \mathrm{mL}^{-1}\right)$ for $1 \mathrm{~h}$, both plant products inhibited NBT reduction in 
the HK macrophages, thus showing a significant decrease in absorbance with increasing concentrations when compared with the control $(0.4 \%$ DMSO) $(P<0.05)$ (Fig. 7). Likewise, the addition of the antioxidant enzyme superoxide dismutase (SOD) (300 $\mathrm{U} \mathrm{mL}^{-1}$ ), to $\mathrm{HK}$ macrophages showed a significant decrease in NBT reduction rate $(P<0.05)$. 


\section{Discussion}

Currently, there has been growing interest in medicinal plants and phytochemical compounds derived from plants as enhancers of the fish immune response against fish pathogens in aquaculture as an alternative to chemicals (Dügenci et al. 2003; Galina et al. 2009; Vaseeharan and Thaya 2014). The understanding of the mechanims behind the effects of medicinal plants on fish immune response at molecular level are indoubtably helpful for proposing appropriate applications in fish farming. In this work, the immunomodulatory potential of both natural plant products, the ethanol extract of $R$. tomentosa ant its active compound, rhodomyrtone was determined focusing on the mRNA levels of innate immune-related genes in macrophages of rainbow trout and on the functional response of ROS production.

Initially, the cytotoxicity of $R$. tomentosa and rhodomyrtone was preliminary tested on the HK macrophages within a concentration range based on their cytotoxicity on mammalian monocytes/macrophages (Jeong et al. 2013; Srisuwan et al. 2014). The results revealed that doses of $R$. tomentosa that have no cytotoxic effects on HK macrophages were lower than $25 \mu \mathrm{g} \mathrm{mL}^{-1}$ in which the solvent (0.4\% DMSO) showed absence of cytotoxicity. Previously, Jeong et al (2013) reported no cytotoxic effects of $R$. tomentosa methanol extract on a murine macrophage cell line (RAW264.7 cells) at 2-fold to 16-fold higher than in the present study.

Rhodomyrtone did not show any cytotoxic effect on the fish HK macrophages at concentrations less than $1 \mu \mathrm{g}$ $\mathrm{mL}^{-1}$, as opposed to a study demonstrating rhodomyrtone toxicity $\left(1.56 \mu \mathrm{g} \mathrm{mL}^{-1}\right)$ on human monocytes (THP-1) (Srisuwan et al. 2014).

Exposition of HK macrophages to $R$. tomentosa resulted in a noticeable upregulation of proinflammatory cytokine, il $\beta$ gene expression after $4 \mathrm{~h}$, while the fish cells exposed to rhodomyrtone showed an increase in the mRNA levels of $i l \beta, i l 8$, and $\operatorname{tnf} \alpha$ genes. In fish, pro-inflammatory cytokines such as IL1 $\beta$, IL8, and TNF $\alpha$ are key players in immune response, stimulating macrophage activation and enhancing the synthesis of inflammatory proteins responsible for antimicrobial defenses and inflammatory reaction (Secombes et al. 2001). Thus, the specific enhancement of the gene expression by the plant substances might promote the activity of the fish macrophages leading to early protective immunity during diseases. In line with our study, Chi et al (2016) observed an upregulation of $i l 1 \beta$ and $t n f \alpha$ mRNA levels in HK macrophages of grass carp (Ctenopharyngodon idella) after exposure to a phytochemical compound extracted from Dryopteris crassirhizoma. Furthermore, in vivo administration of Ficus carica polysaccharide induced an increase in the mRNA levels of $i l 1 \beta$ and tnf $\alpha$, thereby providing resistance to Flavobacterium columnare infection in grass carp 
(Yang et al. 2015). Reyes-Becerril et al (2013) observed modulatory effects on $i l 1 \beta$ and $i l 8$ gene expression of gilthead sea bream (Sparus aurata) after diet supplementation with lyophilized microalgae Navicula sp. Besides, studies with mammalian cells have shown that natural compounds such as anethol, capsicum oleoresin, carvacrol, eugenol, garlicon, and cinnamaldehyde augmented IL1 $\beta$ and TNF $\alpha$ protein secretion of weaned pig macrophages (Liu et al. 2012), possibly indicating a stimulatory effect of the phytochemical compounds on proinflammatory cytokine gene expression in immune cells.

IL10 and TGF $\beta$ are immunosuppressive cytokines responsible for anti-inflammatory reactions thus restricting the inflammatory response to minimize host damage (Zou and Secombes 2016). In the present study, either $i l 10$ or $\operatorname{tg} f \beta$ were unaltered in HK macrophages exposure to $R$. tomentosa. On the other hand, illo or $\operatorname{tg} f \beta$ mRNA transcriptional levels were obviously increased following rhodomyrtone exposure for $24 \mathrm{~h}$. The presence of anti-inflammatory cytokines served as an important negative feedback mechanism to control the expression of pro-inflammatory cytokines, thus balancing stimulatory and inhibitory protein signaling pathways involved in immune responses. Other authors have reported that a recombinant form of IL10 (rgIL10) attenuated the mRNA expression of $\operatorname{tnf} \alpha 1, \operatorname{tnf} \alpha 2, i l 1 \beta 1, \operatorname{cxcl}$, and nadph oxidase component in heat-killed Aeromonas salmonicida activated-monocytes of goldfish (Carassius auratus) (Grayfer et al. 2011). Likewise, the inhibitory effects of a recombinant TGF $\beta 1$ on the expression of $t n f \alpha, i l 1 \beta, i l 8$, and inos via NF-kB signaling by blocking I $\kappa \mathrm{B} \alpha$ (gcI $\mathrm{B} \alpha$; I $\mathrm{B}$ inhibitor) protein secretion in LPS-stimulated macrophages of grass carp have been reported (Wei et al. 2015). Therefore, in the present study, rhodomyrtone might have positive effects on fish immune response to maintain balance and prevent injuries caused by the over expression of pro-inflammatory cytokines.

To further address the immunomodulatory effects of $R$. tomentosa and rhodomyrtone on innate immune defense, we examined the expression patterns of genes involved in inducible enzymes (inos, $\operatorname{cox} 2$, and arginase), saa, hepcidin, and antioxidant enzymes (nadph and gpxl) of rainbow trout HK macrophages. In the present study we observed that $R$. tomentosa had no effect on mRNA abundance of all inducible enzymes and antioxidant enzymes, whereas rhodomyrtone obviously upregulated the expression of inos, cox 2 , and arginase including gpxl gene in the fish cells after $24 \mathrm{~h}$ exposure. This data supports the findings on THP-1 human macrophages exposed to rhodomyrtone, which have shown the potential of this compound to induce nitric oxide production through enhanced expression of the inos gene (Srisuwan et al. 2014). In addition, the immunomodulatory effects of ginsan (Panax ginseng) by increasing inos mRNA level and other major proinflammatory cytokines (e.g. $i l 1 \beta$, il6, and $t n f \alpha$ ) in comparison with LPS/IFN $\gamma$ stimulation in murine peritoneal macrophages have been reported (Song et al. 2002). In animal models, ginger (Zingiber officinale) has been 
found to possess an antioxidant protective efficacy for chemoprevention of liver diseases by enhancing mRNA expression of antioxidant genes such as gpxl, gst 1 (glutathione S transferase $\alpha 1$ ), and cat (catalase) in rats (Mohamed et al. 2015).

We found that after co-exposition of HK macrophages to $R$. tomentosa and LPS, mRNA levels of $i l 1 \beta$, il8, inos, tnfa, saa, hepcidin, and gpxl were dramatically down-regulated, pointing out the anti-inflammatory properties of this plant on the fish immune cells. Previous studies with mammalian cells indicated that proinflammatory cytokine production such as IL1 $\beta$, IL6, and TNF $\alpha$ can be inhibited by quercetin, a flavonoid found in many plants when co-exposed to immunostimulators (e.g. LPS, phorbol 12-myristate 13- acetate) (Cho et al. 2003; Nair et al. 2006). Quercetin acts as an anti-oxidant and anti-inflammatory agent by reducing the

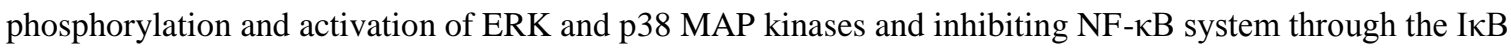
kinase complex, thus blocking pro-inflammatory cytokines and inos expression (Cho et al. 2003). Intriguingly, this compound has also been detected in the methanol extract of $R$. tomentosa (Jeong et al. 2013). Analogous results observed in murine macrophages exposed to $R$. tomentosa demonstrated that the plant extract suppressed the activation of NF- $\mathrm{KB}$ pathway via Syk/Src and AP-1 pathway via IRAK1/IRAK4 signaling, responsible for nitric oxide and prostaglandin E2 productions (Jeong et al. 2013).

In co-exposition to rhodomyrtone and LPS, the plant compound noticeably induced pro-inflammatory gene expression, tnf $\alpha$ in HK macrophages, indicating a synergistic effect between both stimuli, while the mRNA levels of other pro-inflammatory and immune-related genes including ill $\beta$, inos, saa, hepcidin, and gpxl were down regulated. Conversely, in human macrophages, rhodomyrtone did not show any stimulatory effects on $i l 1 \beta$ and $t n f \alpha$ expression, but this compound synergistically enhanced other pro-inflammatory mediators such as $i l 6$ and inos in THP-1 human monocytes exposed to heat-killed multidrug-resistant Staphylococcus aureus (Srisuwan et al. 2014). These contradictory results might be attributed to species differences, co-stimulating sources, and sampling times. In other fish cells, elevated gene expression of $t$ f $f \alpha$ with other pro-inflammatory mediators (e.g. ill $\beta, \operatorname{cox} 2$ ) was found in LPS-activated sea bream fibroblasts during co-incubation with Aloe arborescens leaf extract (Picchietti et al. 2013).

In line with our findings in other animals, oleifolioside A, a triterpenoid compound from Dendropanax morbifera was found to attenuate the expression of inos and cox2 gene in LPS-activated murine macrophage (Yu et al. 2012). Other authors have reported the anti-inflammatory effects of a flavonoid antioxidant silymarin, which depressed the level of inos gene transcription and its protein expression in LPS-induced murine macrophages (Kang et al. 2002). The extracts of Echinacea pallida (Zhai et al. 2009), Grindelia robusta, Salix 
nigra, Arnica montana, and Quassia amara (Verma et al. 2010) suppressed the production of iNOS and COX2 protein in LPS-stimulated macrophages. Recently, an in vivo study revealed that feeding rats with Cichorium intybus root extract caused increase in oxidative stress and hepatotoxicity resulting in suppression of the antioxidant gene transcripts, gpxl, cat, and ponl (El-Sayed et al. 2015). There was no information about the effect of natural products on saa gene transcription, but a reduction in SAA protein in activated-mouse liver cells by colchicine, a secondary metabolite originally isolated from plants of genus Colchicum, has been reported (Tatsuta et al. 1984).

Our results suggest that $R$. tomentosa and rhodomyrtone can inhibit the production of superoxide anion in HK macrophages of rainbow trout. Respiratory burst is a vital mechanism of innate immune defense that occurs in phagocytes, in particular neutrophils and macrophages (Neumann et al. 2001). Superoxide anion is one of the reactive respiratory burst activation byproducts that exert antimicrobial actions against invading pathogens and also play a cytotoxic role in the development of inflammatory response. Superoxide dismutase is an antioxidant enzyme that removes superoxide anion. In this study, it was expected that both $R$. tomentosa and rhodomyrtone would induce SOD production by regulating the expression of sod gene in the fish cells. This might be a protective mechanism to avoid cell damage caused by oxidative stress during upregulation of cytokines and other immune mediators involved in inflammatory response under immunostimulation with the plant substances. A previous study has reported protection against ischemia in rats by upregulation of gene expression of antioxidant enzymes (cat, gpx, and sod), while increaseasing pro-inflammatory cytokine genes $(i l 1 \beta$, il6, and $t n f \alpha)$ during myocardial ischemia/reperfusion process in animal models (Chandrasekar et al. 1997). Similar results were observed in mouse peritoneal macrophages following intraperitoneal administration of Hippophae salicifolia bark extract (Chakraborty et al. 2016). This plant extract also prevents oxidative DNA damage, lipid peroxidation, and reduces glutathione in the mouse macrophages.

\section{Conclusions}

The present results show, for the first time in fish, the intrinsic immunomodulatory effects of the natural plant products, $R$. tomentosa and rhodomyrtone on the expression of genes related to innate immune response in rainbow trout $\mathrm{HK}$ macrophages by inducing the mRNA levels of certain pro-inflammatory cytokines, anti-inflammatory cytokines, inducible enzymes, and antioxidant enzymes. In LPS-triggered HK macrophages, $R$. tomentosa and rhodomyrtone possessed an anti-inflammatory effect by acting as an inhibitor of the gene expression of pro-inflammatory cytokines, acute phase proteins, and oxidant enzymes. In addition, both 
plant substances significantly decreased the production of ROS in the fish cells. According to their pronounced effects, this study expands the information on the phyto-immunomodulatory effects of specific plant products as possible enhancers of fish immunity, being valuable useful scientific data and a potential tool for further utilization in aquaculture. 
Acknowledgements This work was funded by the Higher Education Research Promotion and National Research University Project of Thailand, Office of the Higher Education Commission for Ph.D. scholarship, TRF Senior Research Scholar (Grant No. RTA5880005), the Faculty of Science Research Fund in fiscal year 2015, Faculty of Science, Prince of Songkla University, and AGL2013-48835-C2 of MINECO (Spain). L Tort, M Teles, and C Fierro-Castro are members of the Xarxa d'Aquicultura de Catalunya. M Teles have a postdoctoral fellowship from FCT (SFRH/BPD/109219/2015) supported by the European Social Fund and national funds from the "Ministério da Educação e Ciência (POPH - QREN - Tipologia 4.1)" of Portugal. JC Balasch is thankfully acknowledged for the graphic design of the figures.

\section{References}

Chakraborty M, Karmakar I, Haldar S, Das A, Bala A, Haldar PK (2016) Amelioration of oxidative DNA damage in mouse peritoneal macrophages by Hippophae salicifolia due to its proton $\left(\mathrm{H}^{+}\right)$donation capability: Ex vivo and in vivo studies. J Pharm Bioall Sci 8:210-216

Chandrasekar B, Colston J, Freeman G (1997) Induction of proinflammatory cytokine and antioxidant enzyme gene expression following brief myocardial ischaemia. Clin Exp Immunol 108:346-351

Chakraborty SB, Hancz C (2011) Application of phytochemicals as immunostimulant, antipathogenic and antistress agents in finfish culture. Rev Aquacult 3:103-119

Chi C, Giri SS, Jun JW, Kim HJ, Yun S, Kim SG, Park SC (2016) Immunomodulatory effects of abioactive compound Isolated from Dryopteris crassirhizoma on the grass carp Ctenopharyngodon idella. J Immunol Res 2016 May 15:2016

Cho SY, Park SJ, Kwon MJ, Jeong TS, Bok SH, Choi WY, Jeong WI, Ryu SY, Do SH, Lee CS (2003) Quercetin suppresses proinflammatory cytokines production through MAP kinases and NF-kB pathway in lipopolysaccharide-stimulated macrophage. Mol Cell Biochem 243:153-160

Chung S, Secombes CJ (1988) Analysis of events occurring within teleost macrophages during the respiratory burst. Comp. Biochem. Physiol. B, Biochem. Mol Biol 89:539-544

Dügenci SK, Arda N, Candan A (2003) Some medicinal plants as immunostimulant for fish. J Ethnopharmacol $88: 99-106$ 
El-Sayed YS, Lebda MA, Hassinin M, Neoman SA (2015) Chicory (Cichorium intybus L.) root extract regulates the oxidative status and antioxidant gene transcripts in CCl4-induced hepatotoxicity. PLoS ONE 10:e0121549

Fent K (2001) Fish cell lines as versatile tools in ecotoxicology: assessment of cytotoxicity, cytochrome P4501A induction potential and estrogenic activity of chemicals and environmental samples. Toxicol In Vitro 15:477-488

Fierro-Castro C, Barrioluengo L, López-Fierro P, Razquin B, Carracedo B, Villena A (2012) Fish cell cultures as in vitro models of pro-inflammatory responses elicited by immunostimulants. Fish Shellfish Immunol 33:389-400

Fierro-Castro C, Barrioluengo L, López-Fierro P, Razquin B, Villena A (2013) Fish cell cultures as in vitro models of inflammatory responses elicited by immunostimulants. Expression of regulatory genes of the innate immune response. Fish Shellfish Immunol 35:979-987

Galina J, Yin G, Ardo L, Jeney Z (2009) The use of immunostimulating herbs in fish. An overview of research. Fish Physiol Biochem 35:669-676

Grayfer L, Hodgkinson JW, Hitchen SJ, Belosevic M (2011) Characterization and functional analysis of goldfish (Carassius auratus L.) interleukin-10. Mol Immunol 48:563-571

Harikrishnan R, Balasundaram C, Heo MS (2011) Impact of plant products on innate and adaptive immune system of cultured finfish and shellfish. Aquaculture 317:1-15

Hiranrat A, Mahabusarakam W (2008) New acylphloroglucinols from the leaves of Rhodomyrtus tomentosa. Tetrahedron 64:11193-11197

Jeong D, Yang WS, Yang Y, Nam G, Kim JH, Yoon DH, Noh HJ, Lee S, Kim TW, Sung GH (2013) In vitro and in vivo anti-inflammatory effect of Rhodomyrtus tomentosa methanol extract. J Ethnopharmacol $146: 205-213$

Kang JS, Jeon YJ, Kim HM, Han SH, Yang KH (2002) Inhibition of inducible nitric-oxide synthase expression by silymarin in lipopolysaccharide-stimulated macrophages. J Pharmacol Exp Ther 302:138-144

Lavanya G, Voravuthikunchai SP, Towatana NH (2012) Acetone extract from Rhodomyrtus tomentosa: a potent natural antioxidant. Evid Based Complement Alternat Med 2012

Limsuwan S, Trip EN, Kouwen TR, Piersma S, Hiranrat A, Mahabusarakam W, Voravuthikunchai SP, Van Dijl JM, Kayser O (2009) Rhodomyrtone: a new candidate as natural antibacterial drug from Rhodomyrtus tomentosa. Phytomedicine 16:645-651 
Liu Y, Song M, Che T, Bravo D, Pettigrew J (2012) Anti-inflammatory effects of several plant extracts on porcine alveolar macrophages in vitro. J Anim Sci 90:2774-2783

Manu K, Kuttan G (2008) Ursolic acid induces apoptosis by activating p53 and caspase-3 gene expressions and suppressing NF- $\mathrm{KB}$ mediated activation of bcl-2 in B16F-10 melanoma cells. Int Immunopharmacol 8: 974-981

Mordmuang A, Voravuthikunchai SP (2015) Rhodomyrtus tomentosa (Aiton) Hassk. leaf extract: An alternative approach for the treatment of staphylococcal bovine mastitis. Res Vet Sci 102:242-246.

Mohamed OI, El-Nahas AF, El-Sayed YS, Ashry KM (2016) Ginger extract modulates Pb-induced hepatic oxidative stress and expression of antioxidant gene transcripts in rat liver. Pharm Biol 54:1164-1172

Nair MP, Mahajan S, Reynolds JL, Aalinkeel R, Nair H, Schwartz SA, Kandaswami C (2006) The flavonoid quercetin inhibits proinflammatory cytokine (tumor necrosis factor alpha) gene expression in normal peripheral blood mononuclear cells via modulation of the NF-kB system. Clin Vaccine Immunol $13: 319-328$

Neumann NF, Stafford JL, Barreda D, Ainsworth AJ, Belosevic M (2001) Antimicrobial mechanisms of fish phagocytes and their role in host defense. Dev Comp Immunol 25:807-825

Pfaffl MW (2001) A new mathematical model for relative quantification in real-time RT-PCR. Nucleic Acids Res 29:e45-e45

Picchietti S, Bernini C, Belardinelli M, Ovidi E, Taddei A, Guerra L, Abelli L, Fausto A (2013) Immune modulatory effects of Aloe arborescens extract on the piscine SAF-1 cell line. Fish Shellfish Immunol $34: 1335-1344$

Reyes-Becerril M, Guardiola F, Rojas M, Ascencio-Valle F, Esteban MÁ (2013) Dietary administration of microalgae Navicula sp. affects immune status and gene expression of gilthead seabream (Sparus aurata). Fish Shellfish Immunol 35:883-889

Sakai M (1999) Current research status of fish immunostimulants. Aquaculture 172:63-92.

Secombes C, Wang T, Hong S, Peddie S, Crampe M, Laing K, Cunningham C, Zou J (2001) Cytokines and innate immunity of fish. Dev Comp Immunol 25:713-723

Secombes CJ (1990) Isolation of salmonid macrophages and analysis of their killing activity. Techniques in fish immunology 1:137-154

Song JY, Han SK, Son EH, Pyo SN, Yun YS, Yi SY (2002) Induction of secretory and tumoricidal activities in peritoneal macrophages by ginsan. Int Immunopharmacol 2:857-865 
Srisuwan S, Tongtawe P, Srimanote P, Voravuthikunchai SP (2014) Rhodomyrtone modulates innate immune responses of THP-1 monocytes to assist in clearing methicillin-resistant Staphylococcus aureus. PLoS ONE 9:e110321

Tatsuta E, Sipe JD, Shirahama T, Skinner M, Cohen AS (1984) Colchicine inhibition of serum amyloid protein SAA and SAP synthesis in primary mouse liver cell cultures. Arthritis Rheum 27:349-352

Tung NH, Ding Y, Choi EM, Van Kiem P, Van Minh C, Kim YH (2009) New anthracene glycosides from Rhodomyrtus tomentosa stimulate osteoblastic differentiation of MC3T3-E1 cells. Arch Pharm Res $32: 515-520$

Van Hai N (2015) The use of medicinal plants as immunostimulants in aquaculture: A review. Aquaculture 446:88-96

Vaseeharan B, Thaya R (2014) Medicinal plant derivatives as immunostimulants: an alternative to chemotherapeutics and antibiotics in aquaculture. Aquac Int 22:1079-1091

Verma N, Tripathi SK, Sahu D, Das HR, Das RH (2010) Evaluation of inhibitory activities of plant extracts on production of LPS-stimulated pro-inflammatory mediators in J774 murine macrophages. Mol Cell Biochem 336:127-135

Villasante A, Powell MS, Moutou K, Murdoch GK, Overturf K, Wacyk J, Hardy RW (2016) Effects of anthocyanidins on myogenic differentiation and antioxidant defense in primary myogenic cells isolated from rainbow trout (Oncorhynchus mykiss). Aquaculture 454:81-89

Wangkahart E, Scott C, Secombes CJ, Wang T (2016) Re-examination of the rainbow trout (Oncorhynchus mykiss) immune response to flagellin: Yersinia ruckeri flagellin is a potent activator of acute phase proteins, anti-microbial peptides and pro-inflammatory cytokines in vitro. Dev Comp Immunol 57:75-87

Wang Y, Aker WG, Hwang HM, Yedjou CG, Yu H, Tchounwou PB (2011) A study of the mechanism of in vitro cytotoxicity of metal oxide nanoparticles using catfish primary hepatocytes and human HepG2 cells. Sci Total Environ 409:4753-4762

Wei H, Yin L, Feng S, Wang X, Yang K, Zhang A, Zhou H (2015) Dual-parallel inhibition of IL-10 and TGFb1 controls LPS-induced inflammatory response via NF-kB signaling in grass carp monocytes/macrophages. Fish Shellfish Immunol 44:445-452 
Yang X, Guo JL, Ye JY, Zhang YX, Wang W (2015) The effects of Ficus carica polysaccharide on immune response and expression of some immune-related genes in grass carp, Ctenopharyngodon idella. Fish Shellfish Immunol 42:132-137

Yin G, Cao L, Xu P, Jeney G, Nakao M, Lu C (2011) Hepatoprotective and antioxidant effects of Glycyrrhiza glabra extract against carbon tetrachloride $\left(\mathrm{CCl}_{4}\right)$-induced hepatocyte damage in common carp (Cyprinus carpio). Fish Physiol Biochem 37:209-216

Yu HY, Kim KS, Lee YC, Moon HI, Lee JH (2012) Oleifolioside A, a new active compound, attenuates LPSstimulated iNOS and COX-2 expression through the downregulation of NF-kB and MAPK activities in RAW 264.7 macrophages. Evid Based Complement Alternat Med 2012

Zhai Z, Solco A, Wu L, Wurtele ES, Kohut ML, Murphy PA, Cunnick JE (2009) Echinacea increases arginase activity and has anti-inflammatory properties in RAW 264.7 macrophage cells, indicative of alternative macrophage activation. J Ethnopharmacol 122:76-85

Zou J, Secombes CJ (2016) The Function of Fish Cytokines. Biology 5:23 
Table 1 Primers used for mRNA analysis by real-time PCR

\begin{tabular}{|c|c|c|c|c|}
\hline Gene name & Acronym & $\begin{array}{l}\text { GenBank } \\
\text { accession }\end{array}$ & Forward & Reverse \\
\hline Interleukin $1 \beta$ & $i l 1 \beta$ & AJ223954 & GGATTCACAAGAACTAAGGAC & ACTGTGATGTACTGCTGAAC \\
\hline Interleukin 8 & $i l 8$ & AJ279069 & GAATGTCAGCCAGCCTTGTC & TCCAGACAAATCTCCTGACCG \\
\hline Tumor necrosis factor- $\alpha$ & $\operatorname{tnf} \alpha$ & $\mathrm{AJ} 277604$ & AGCATGGAAGACCGTCAACGAT & ACСCTCTAAATGGATGGCTGCTT \\
\hline Interleukin 10 & $i l 10$ & AB118099 & CGACTTTAAATCTCCCATCGAC & GCATTGGACGATCTCTTTCTT \\
\hline $\begin{array}{l}\text { Transforming growth factor } \\
\text { beta }\end{array}$ & $\operatorname{tg} f \beta$ & OMY7836 & CTCACATTTTACTGATGTCACTTCCTGT & GGACAACTGCTCCACCTTGTG \\
\hline Inducible nitric oxide synthase & inos & AJ295231 & CCAACCATGCACATCAAAAGTT & CCTGAGGTAGGATTTCAAGAGTAGAAA \\
\hline Cyclooxygenase 2 & $\cos 2$ & AJ 238307 & АТССТТАСТСАСТАСАAАGG & GCTGGTCCTTTCATGAAGTCTG \\
\hline Arginase & arginase & AY056477 & TGGGAGCCGGACACACTAC & GCCTTCCACTGAACCAATGG \\
\hline Serum amyloid A & saa & AM422447 & GGTGAAGCTGCTCAAGGTGCTAAAG & GCCATTACTGATGACTGTTGCTGC \\
\hline Hepcidin & hepcidin & CA369786 & GCTGTTCCTTTCTCCGAGGTGC & GTGACAGCAGTTGCAGCACCA \\
\hline $\begin{array}{l}\text { Nicotinamide adenine } \\
\text { dinucleotide phosphate oxidase }\end{array}$ & nadph & AB192465.1 & CATCGCCCACCTGTTTAACT & GTATGACCTGCGGATGACCT \\
\hline Glutathione peroxidase 1 & gpxl & BG934453 & GATTCGTTCCAAACTTCCTGCTA & GCTCCCAGAACAGCCTGTTG \\
\hline Elongation factor- $1 \alpha$ & efla & AF498320 & CAAGGATATCCGTCGTGGCA & ACAGCGAAACGACCAAGAGG \\
\hline
\end{tabular}




\section{Figure legends}

Fig. 1 Cytotoxicity of Rhodomyrtus tomentosa leaf extract (RT) and rhodomyrtone (RD) on rainbow trout head kidney macrophages. Control cells were exposed to medium containing 0.4\% DMSO. Results were expressed as mean values of triplicate independent experiments \pm SD $(n=3$ biological replicates). Single asterisks indicate significant differences from $0.4 \%$ DMSO (Control) at $P<0.05(*), P<0.01(* *)$. There were no significant difference between non treatment (100\% viability) and DMSO treatment

Fig. 2 Relative mRNA expression levels of interleukin $1 \beta(i l 1 \beta)$, interleukin 8 (il8), and tumour necrosis factor$\alpha(t n f \alpha)$ in rainbow trout head kidney (HK) macrophages exposed to Rhodomyrtus tomentosa leaf extract (RT; $\left.10 \mu \mathrm{g} \mathrm{mL}^{-1}\right)$ and rhodomyrtone (RD; $1 \mu \mathrm{g} \mathrm{mL}^{-1}$ ) alone or combined with LPS $\left(5 \mu \mathrm{g} \mathrm{mL}^{-1}\right)$ for 4 and $24 \mathrm{~h}$. Bars represent the mean $\pm \mathrm{SD}$ of relative mRNA expression as a fold change relative to elongation factor $1 \alpha($ efl $\alpha)$ (n $=3$ biological replicates $)$. Significant differences are: $*$ vs. control $(* P<0.05, * * P<0.01), \wedge_{\text {vs. difference }}$ between 4 and $24 \mathrm{~h}(\boldsymbol{\Delta} P<0.05, \stackrel{\Delta}{\Delta} P<0.01)$

Fig. 3 Relative mRNA expression quantities interleukin 10 (illo) and transforming growth factor beta $(\operatorname{tg} f \beta)$ in rainbow trout head kidney $(\mathrm{HK})$ macrophages exposed to Rhodomyrtus tomentosa leaf extract $\left(\mathrm{RT} ; 10 \mu \mathrm{g} \mathrm{mL} \mathrm{m}^{-1}\right)$ and rhodomyrtone (RD; $\left.1 \mu \mathrm{g} \mathrm{mL}^{-1}\right)$ alone or combined with LPS $\left(5 \mu \mathrm{g} \mathrm{mL}^{-1}\right)$ for 4 and $24 \mathrm{~h}$. Bars represent the mean $\pm \mathrm{SD}$ of relative mRNA expression as a fold change relative to elongation factor $1 \alpha(e f 1 \alpha)(\mathrm{n}=3$ biological replicates). Significant differences are: $*$ vs. control $(* P<0.05, * * P<0.01),{ }^{\boldsymbol{\Delta}}$ vs. difference between 4 and $24 \mathrm{~h}(\boldsymbol{\Delta} P<0.05, \Delta \wedge P<0.01)$

Fig. 4 Relative mRNA expression quantities of nitric oxide synthase (inos), cyclooxygenase-2 (cox2) and arginase in rainbow trout head kidney (HK) macrophages exposed to Rhodomyrtus tomentosa (RT; $10 \mu \mathrm{g} \mathrm{mL} \mathrm{m}^{-1}$ ) and rhodomyrtone (RD; $\left.1 \mu \mathrm{g} \mathrm{mL}^{-1}\right)$ alone or combined with LPS $\left(5 \mu \mathrm{g} \mathrm{mL}^{-1}\right)$ for 4 and $24 \mathrm{~h}$. Bars represent the mean $\pm \mathrm{SD}$ of relative mRNA expression as a fold change relative to elongation factor $1 \alpha(e f 1 \alpha)(\mathrm{n}=3$ biological replicates). Significant differences are: $*$ vs. control $(* P<0.05, * * P<0.01),{ }^{\wedge}$ vs. difference between 4 and $24 \mathrm{~h}(\boldsymbol{\Delta} P<0.05, \Delta \mathbf{\Delta} P<0.01)$

Fig. 5 Relative mRNA expression quantities of serum amyloid A ( saa), hepcidin, NADPH oxidase (nadph), and glutathione peroxidase 1 (gpxl) in rainbow trout head kidney (HK) macrophages exposed to Rhodomyrtus 
tomentosa leaf extract (RT; $\left.10 \mu \mathrm{g} \mathrm{mL}^{-1}\right)$ and rhodomyrtone $\left(\mathrm{RD} ; 1 \mu \mathrm{g} \mathrm{mL} \mathrm{m}^{-1}\right)$ alone or combined with LPS (5 $\mu \mathrm{g}$ $\mathrm{mL}^{-1}$ ) for 4 and $24 \mathrm{~h}$. Bars represent the mean $\pm \mathrm{SD}$ of relative mRNA expression as a fold change relative to elongation factor $1 \alpha(e f 1 \alpha)(\mathrm{n}=3$ biological replicates $)$. Significant differences are: * vs. control $(0.4 \%$ DMSO) $\left({ }^{*} P<0.05, * * P<0.01\right),{ }^{\wedge}$ vs. difference between 4 and $24 \mathrm{~h}\left({ }^{\boldsymbol{\Delta}} P<0.05,{ }^{\wedge}{ }^{\star} P<0.01\right)$

Fig. 6 Relative mRNA expression quantities of interleukin $1 \beta($ ill $\beta)$, interleukin 8 (il8), tumour necrosis factor- $\alpha$ $(\operatorname{tnf} \alpha)$, interleukin $10(\mathrm{ill0})$, transforming growth factor beta $(\operatorname{tg} f \beta)$, inducible nitric oxide synthase $($ inos $)$, cyclooxygenase-2 (cox2), arginase, serum amyloid A (saa), hepcidin, NADPH oxidase (nadph), and glutathione peroxidase 1 (gpxl) in rainbow trout head kidney (HK) macrophages exposed to Rhodomyrtus tomentosa leaf extract $\left(\mathrm{RT} ; 10 \mu \mathrm{g} \mathrm{mL}^{-1}\right)$ and rhodomyrtone $\left(\mathrm{RD} ; 1 \mu \mathrm{g} \mathrm{mL}^{-1}\right)$ alone or combined with LPS $\left(5 \mu \mathrm{g} \mathrm{mL}^{-1}\right)$ for 4 and $24 \mathrm{~h}$. Bars represent the mean \pm SD of relative mRNA expression as a fold change relative to elongation factor $1 \alpha(e f l \alpha)\left(\mathrm{n}=3\right.$ biological replicates). Significant difference are $*$ vs. control $(* P<0.05, * * P<0.01),{ }^{\boldsymbol{\Delta}}$ vs. LPS $\left({ }^{\Delta} P<0.05, \Delta{ }^{\Delta} P<0.01\right)$

Fig. 7 Percent of NBT reduction in rainbow trout HK macrophages after exposed to $R$. tomentosa leaf extract (RT; 10, 50, and $100 \mu \mathrm{g} \mathrm{mL}^{-1}$ ) and rhodomyrtone (RD; 1, 2, and $4 \mu \mathrm{g} \mathrm{mL}^{-1}$ ) for $1 \mathrm{~h}$. Results were expressed as mean values of duplicate independent experiments \pm SD ( $n=3$ biological replicates). The cells treated with SOD (300 $\left.\mathrm{U} \mathrm{mL}^{-1}\right)$ were used as a positive control. Single asterisks indicate significant differences from $0.4 \%$ DMSO (Control) at $P<0.05(*), P<0.01(* *)$. There were no significant difference between non treatment (100\% NBT reduction) and DMSO treatment 
Fig. 1

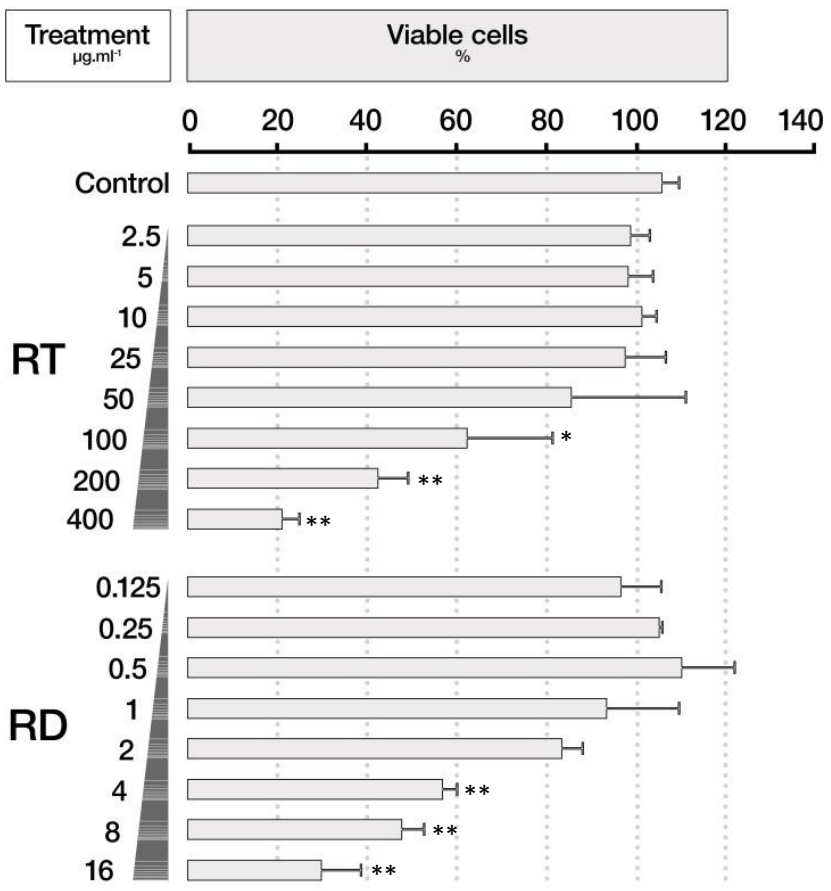


Fig. 2

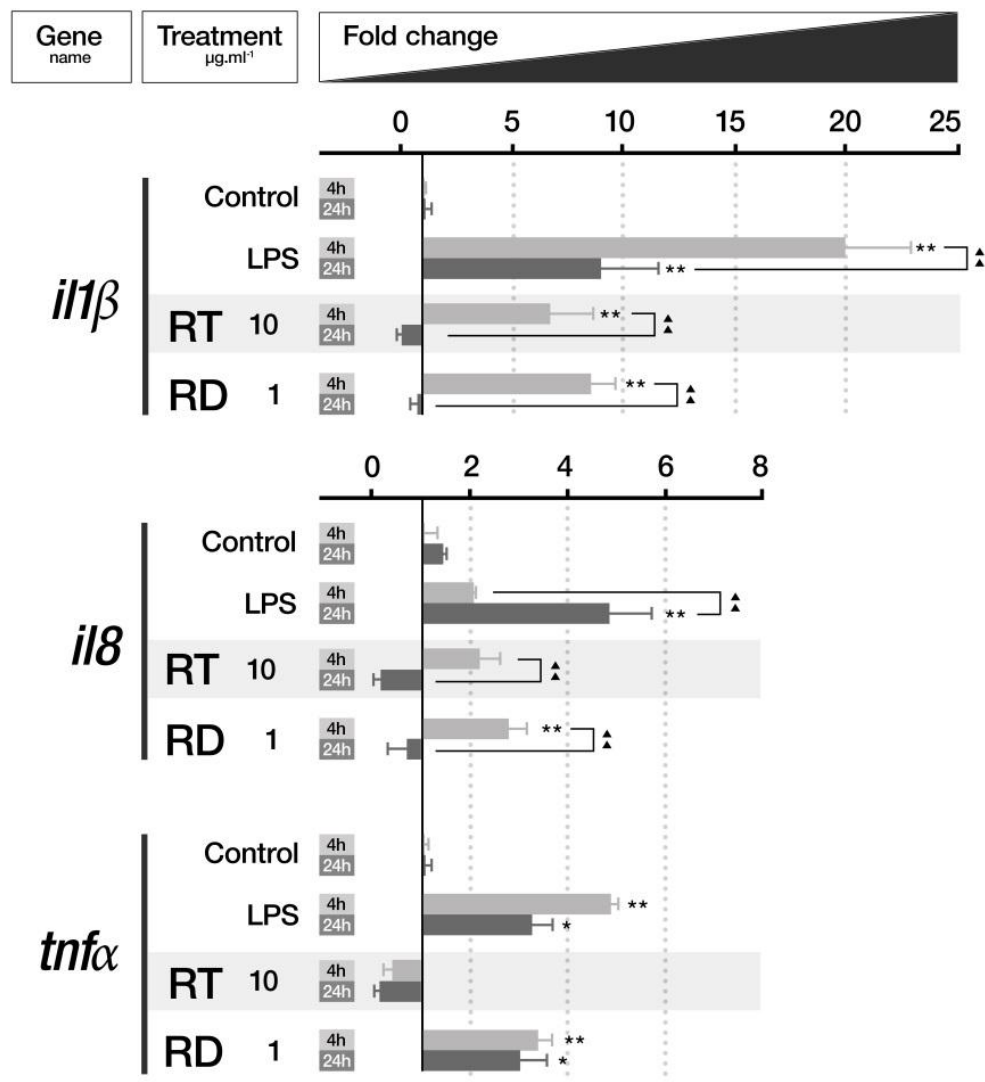


Fig. 3
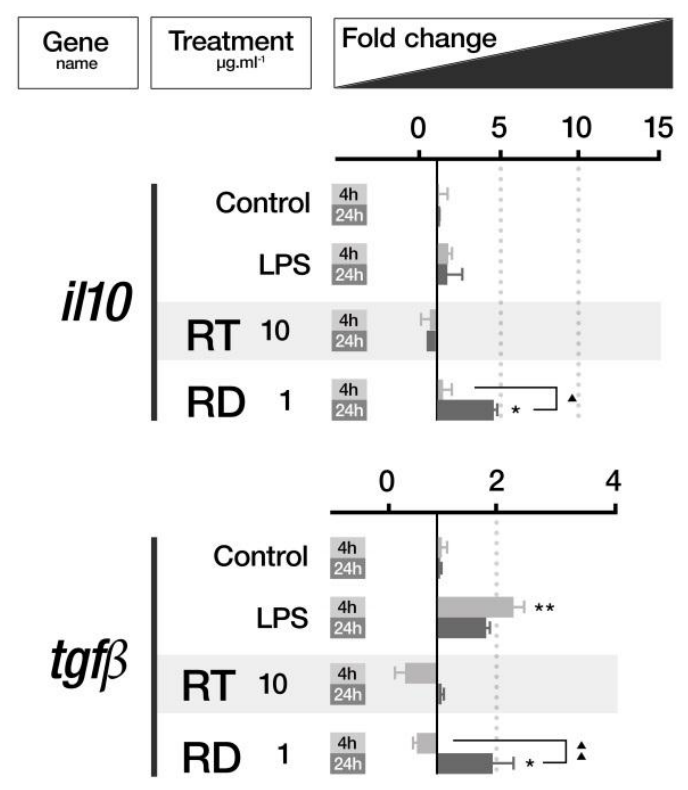
Fig. 4

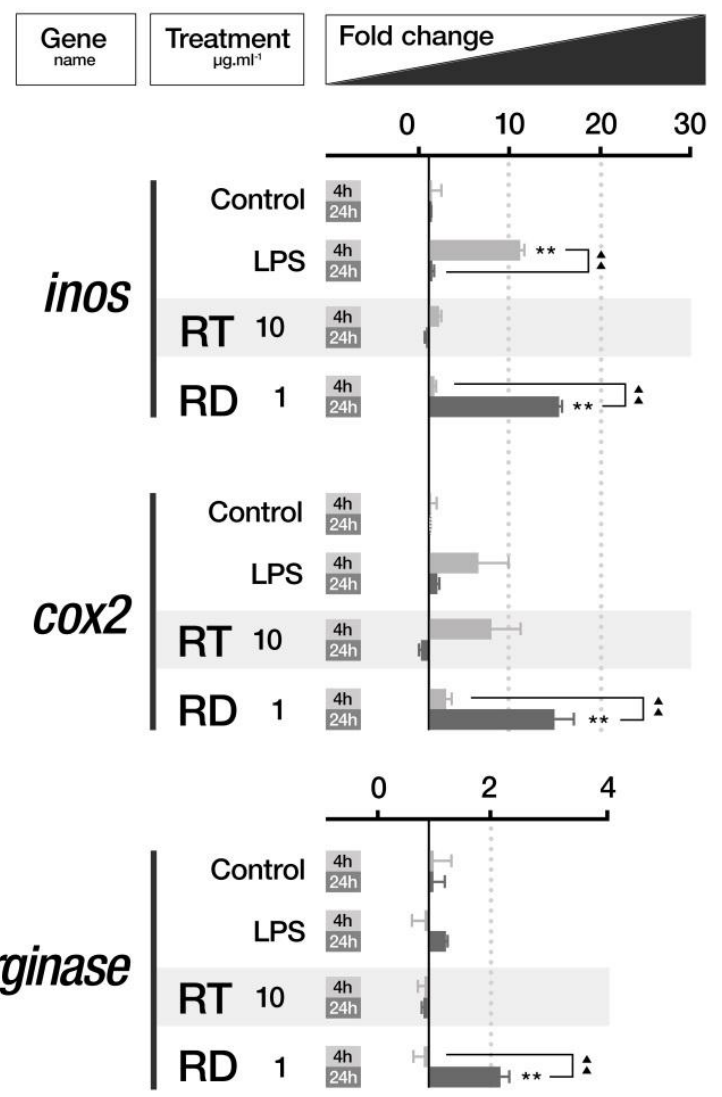


Fig. 5

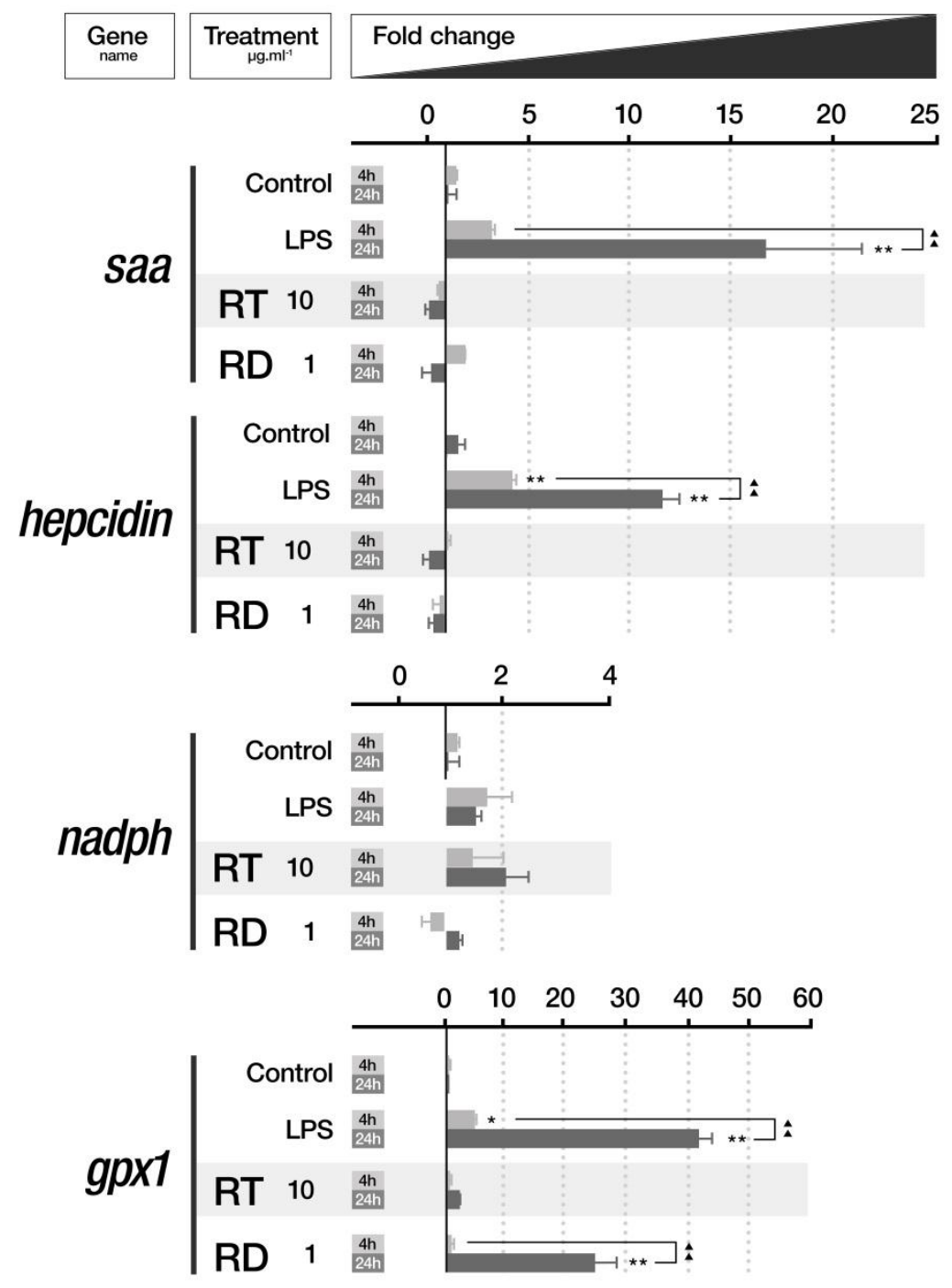



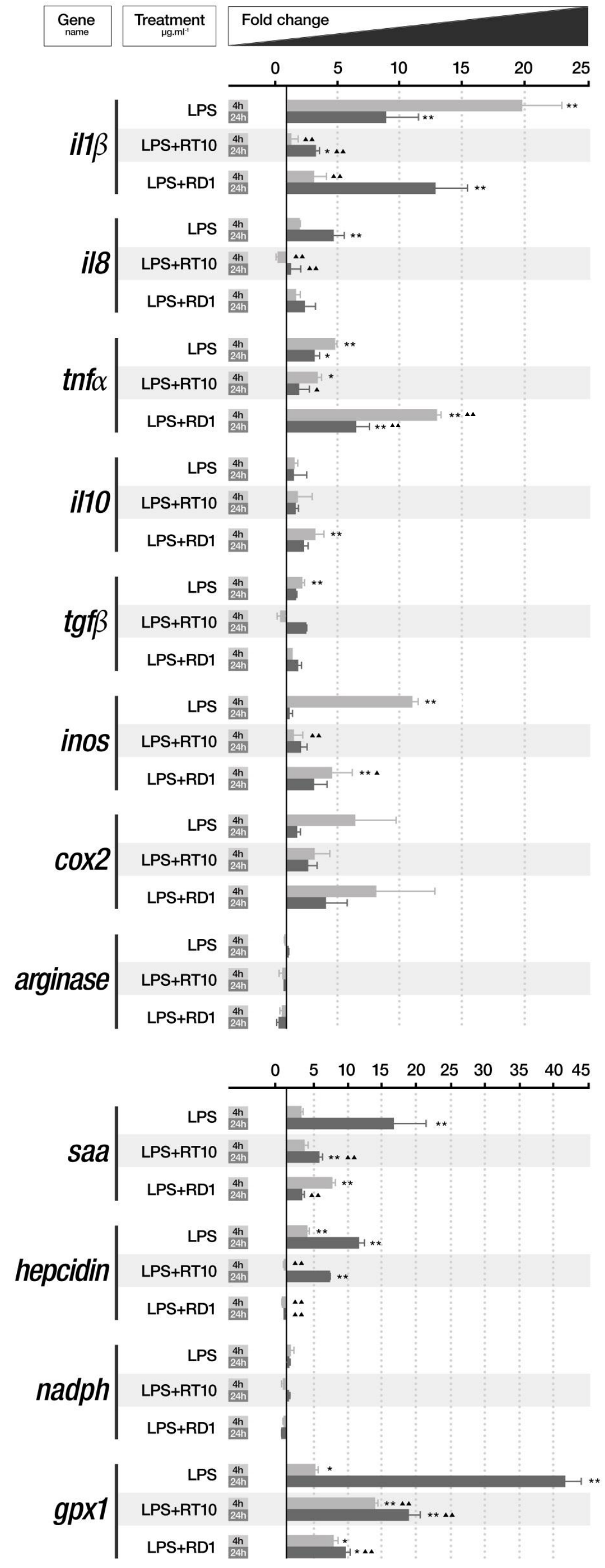
Fig. 7

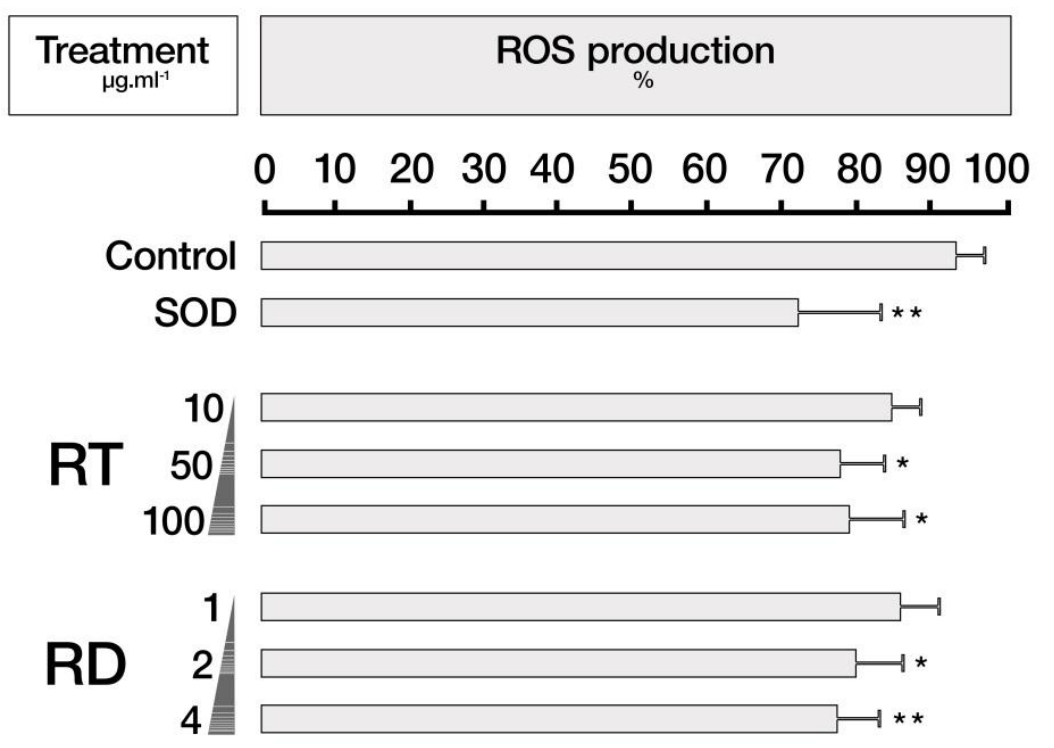

